\title{
Communes' Revenues from Leasing Rights to Use Municipal Properties
}

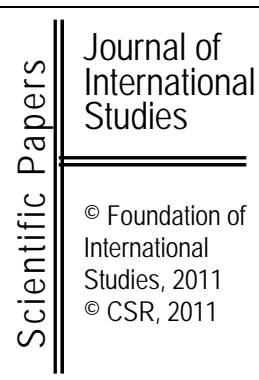

\author{
Associated Prof. Maria Trojanek \\ Department of Investment and Real Estate \\ Faculty of Management \\ Poznań University of Economics \\ m.trojanek@ue.poznan.pl
}

\begin{abstract}
Properties are one of the components of communal assets, and as such they play various roles in the local government's tasks. Property management types are therefore dependent on the classification of properties according to the functions they serve. The aim of the study is to present the reasons for choosing certain forms of municipal property management. Furthermore, the author seeks to describe communes' revenues from sublicensing the rights to properties to other entities.
\end{abstract}

Submitted: September, 2011 $1^{\text {st }}$ revision: October, 2011 Accepted: November, 2011

Keywords: communes' revenues, estate market, municipal properties, Poland.

JEL classification: E32, R33, P2.

\section{Introduction}

Public properties owned by communes serve mainly for public utility on the given area. They are source of financial benefits for communes. Management of particular property stock parts may affect communes' own revenue flows, depending on:

- type of commune,

- diversification of size and substance of the stock,

- policy line (or lack thereof).

Thus, it is essential to carefully choose the use of municipal properties.

\section{Choice of public property management style}

The main (strategic) aim of managing commune-owned properties is the efficient use of the subject properties in the process of rendering public services by the commune, i.e. meeting common needs of the community by delivering local public goods. Specific aims of property management vary according to the functions properties serve. Public properties owned by communities may be used for:

- accomplishing communes' statutory tasks (both administrative and public benefit ones),

- generating one-off income flows (sale) or periodic ones (e.g. lease and rental fees),

- carrying out investment projects, or providing resources for development goals in the future.

Activities related to properties located within the community's borders, but belonging 
to other entities constitute the second field of property management in a community. The community's role in such situations is indirect, as opposed to managing properties owned by communes. In such cases, the community acts as a local host, local development and spatial policy authority, for which property management is one of the elements of the integrated and coherent development policy.

The strategic goal of property management with focus on the subject property stock, is establishing and developing the local space in accordance with the local development goals stipulated in the study of land use and development, as well as in the commune's development strategy. The aim is to provide the optimal functioning of the local socioeconomic system in conformity with principles of sustainable development. Property management earns a considerable share of the commune's budget incomes. Some of the income sources are directly or indirectly connected to the property management performed by the local governments.

Properties located within the community's borders, owned by the local government or any other body, constitute the commune's statutory income source. There are different sources and forms of income generated in the process of property management. Reference books enlist many types of income classification (Bordo, 2004, Patrzałek, 2004, Ruśkowski and Sałachna, 2007, Dylewski and others, 2006, Łaguna, 2002, Miszczak, 2009, Cymerman, 2009). The financial benefits may vary depending on the type of commune (rural, ruralmunicipal and municipal), the size and variety of its stock, adopted strategy (or lack thereof) and the use of such properties.

Referring to the research topic defined in the introduction, the focus of the study is the description of communes' revenues from sublicensing the rights to use their properties. The revenues comprise:

- income from property sale,

- payments (fees) for perpetual usufruct,

- payments (fees) for permanent management of properties,

- rental, easement and usufruct fees.

\section{Sale, perpetual usufruct or leasing municipal land out - choosing the right solution}

Incomes generated by municipal properties have a great share in the overall commune's revenues. Communes may not only sell or buy freehold rights, but also other bundles of rights to properties. The most common rights comprise: perpetual usufruct, lease, rent and permanent management. They generate specific inflows to communes' budgets.

As an example, granting perpetual usufruct to municipal land brings commune the following revenues: the first payment amounting to $15 \%-25 \%$ of the price of the land, and the annual rents (the "fees") for the right of perpetual usufruct. The fees range from $1 \%$ to $3 \%$ of the property value. The municipal council may reduce the fee depending on the applied land use. Selling municipal housing units to current tenants is perceived as economical - it saves money that otherwise would have to be spent on daily running, maintenance and renovations of the municipal buildings, as well as on management of common areas.

The financial effects of selling commune-owned properties may be considered sources of short-term and long-term revenues. It is often the case that the commune treats selling its properties as an expedient way of repairing the budget and financing current costs.

Not all decisions to sell commune-owned properties are equally good. The sale of municipal dwellings, especially if the stock is of a low standard, is undoubtedly more profitable than selling land that otherwise could be used for a commercial purpose. Nowadays, the money obtained from sale of commune-owned properties often covers current costs. 
Selling commune-owned properties diminishes the stock, and limits the income from this source in the future. This in turn may reflect badly on the commune's financial situation and its possibility to meet community's housing needs in some time. Generally, sale of commune-owned properties should be treated as one-off sources of incomes for communal budgets, while revenues from other forms of property right transfers should bring communes relatively regular and stable sources of incomes over longer periods.

Furthermore, sale of commune-owned properties (especially land) limits the possibility to manage them in the future, i.e. they will not be used as in-kind contributions to companies, and no public purpose investments will be located there). The commune loses a source of cash inflows from annual fees for perpetual usufruct, lease or permanent management.

The two main sources of law regulating sale of municipal properties are the Civil Code and the Property Management Act ${ }^{1}$. Selling public properties requires that the local government imposes competitive tender procedures. According to the Property Management Act art. 37, the procedures may be waived (and the rules of competitive negotiations applied) in cases where:

- persons have statutory priority to buy a particular property (e.g. if a flat is purchased by a tenant who entered an agreement for an indefinite time),

- there is a transfer of rights between the State Treasury and the units of local government (province, district or commune) or between these units,

- the buyer is engaged in nonprofit activities, or it is a public benefit organization pursuing its statutory goals,

- there is an exchange or donation,

- the buyer is a perpetual usufructuary of the land,

- the subject property improves the use of the adjacent property,

- the land is an in-kind contribution to a company,

- the buyer manages the special economic zone, and the subject property is located within the zone,

- the seller disposes of the property to the benefit of other co-owners,

- the buyer is Church or a religious community,

- the buyer is a private partner or a company based on private-public partnership,

- the buyer is a special purpose vehicle formed in connection with preparation works to the European Football Championship.

Furthermore, the commune council may waive the competitive tender procedures by resolution in case where:

- the land is to be used for housing purposes (buildings, technical infrastructure or other public purposes) by non-profit organizations whose statutory goal is housing provision and who reinvest all incomes in performance of statutory tasks (e.g. the Public Housing Association TBS),

- the lessee is acquiring the land after having developed it, provided that the leasehold agreement was entered for at least 10 years and the lessee was granted a building permission.

The price of property that will be disposed of through competitive tender procedures is estimated on the basis of property valuation carried out by a chartered property valuer. In a no-bid sale, the following rules are applied:

- the asking price in the first tender is no lower than the property's value,

\footnotetext{
${ }^{1}$ The Property Management Act, journal of laws Dziennik Ustaw 2004, No. 261, item 2603, with amendments; the Civil Code, Verbas publishing house, Lublin 2000.
} 
- if the first tender concludes undecided, the asking price in the second tender may be lower than the property's value, yet no less than $50 \%$ of the value,

- the highest price bid for the land is used as a basis for establishing the final price of the subject property,

- if the second tender concludes undecided, the price of the property is defined after competitive negotiations with the prospective buyer, yet it is no less than $50 \%$ of the property's value.

In case of a no-bid sale, the price of the property cannot be lower than its value.

The Property Management Act (art.68) enables commune to grant discounts on the price of property that is subject to no-bid sale. Furthermore, according to the subject act (art. 70), the price may be paid in instalments, yet no longer than 10 years.

Perpetual usufruct ${ }^{2}$ is a long-term land lease (it may last from 40 to 99 years) that grants the lessee the right to keep benefits derived from the public land (belonging to the State Treasury or to the units of local government). It is regulated by the Polish Civil Code (art. 535 -602) and the Property Management Act.

The right of perpetual usufruct may be granted on land owned by the State Treasury or units of local government, i.e. provinces, districts and communes. Usually, the entitled entities impose the right upon land for commercial use (although there are no legal restrictions as to the sale of land of other use). Within the limits of legal acts and the rules of social order the perpetual usufructuary (lessee) is entitled to use the land to the exclusion of other persons and may dispose of his rights within the same limits. The perpetual usufruct has the same attributes as the freehold right: it is freely transferable (it may be the subject of sale), assignable (it may serve as an in-kind contribution) and inheritable (by bequest or by descent). However, there are some differences between the freehold and perpetual usufruct rights:

- the initial usufruct may have a term of 40 to 99 years and can be extended. According to the Civil Code (art. 236), communes are allowed to grant the right for a shorter period, yet no less than 40 years, if the land is to serve a commercial purpose that does not require granting the right for a period of 99 years;

- if the perpetual usufructuary has not developed the land by the deadline defined in the agreement establishing the right, the deadline may be postponed. If the extra deadline is missed, extra charges may be imposed irrespective of the annual payments;

- for the duration of his right the perpetual usufructuary is obliged to pay fees.

The first payment is charged under the transfer of the perpetual usufruct right, while the annual payments are charged until the contract expires with the exception of the year, when the perpetual usufruct right was granted. The first payment (that ranges from $15 \%$ to $25 \%$ ), and the ground rent percentage rate (from $0,3 \%, 1 \%$ and $3 \%$ ) depend on the type of land use stipulated in the agreement. In case where the right was granted for more than one purpose, the percentage rate is determined for the purpose described in the agreement as main. Finally, for other land uses the percentage rate $(3 \%)$ may be revalued by resolution (yet before the right of perpetual usufruct is granted). The annual fees may be revalued, though not more often than once in three years, with the provision that the value of the property increased. The revalued annual fee is established on the basis of the former percentage rate applied to the value of the real property on the date of revaluation. The Property Management Act (art. 73) enables communes to grant special discounts on these payments. The commune head (mayor, city mayor) may after obtaining a permission from the municipal council, grant discounts on

\footnotetext{
${ }^{2}$ The right of perpetual usufruct was introduced to the Polish law with the Act on Administration of Municipal and Housing Estate Areas of 14 July 1961 (journal of laws Dziennik Ustaw, No. 32, item. 159, with amendments). It is a law which regulates the issue of developing another's land, e.g. land belonging to the State Treasury or units of local government.
} 
the first payment or annual fees, if the properties:

- are to be used for public purposes (e.g. housing purposes and infrastructure),

- are listed in the national register of historic monuments,

- are used by low-income citizens for housing purpose.

The first payment and the annual fees for the right of perpetual usufruct generate revenues for the commune's budget for the duration of the agreement, whereas sale is a oneoff source of income. As for the investors, obtaining the perpetual usufruct right gives them the possibility to carry out investments without taking burden of land purchase. Another advantage is the long duration of the right, the possibility to derive benefits from the land and to recover expenditures.

Land lease is a form of property use that lasts for a fixed period of time, and is alternative to sale or perpetual usufruct right (of state-owned land). Plots of land, that have some prospects for development and may be used for other purposes in the future, should not be sold. Lack of management strategy for the property stock, lack of the area development plans, individual investors willing to invest in some particular areas, along with the limited possibilities of carrying out the investment projects due to the communes' financial condition weigh in favour of temporary development of the land. Therefore, it is necessary to lease land to the entities that are interested in such a form of land administration.

In accordance with the law regulations within the civil-legal relations, local government units may grant individuals or legal entities the rights to use properties belonging to these units, by entering rental or lease agreement.

The Civil Code clauses hereof (no. 659 - 709) contain the legal regulation ${ }^{3}$ of rental and lease agreements, as subjects to civil law. In accordance with the Civil Code article 693, under the lease agreement the landlord agrees to lease the object of the agreement to the tenant to use and derive benefits from it for a fixed or indefinite period of time. The tenant pledges in return to pay the fixed fee to the leaseholder. The economic effects of the lease agreement concern the benefits and lease rates. In the free market conditions, an increase in demand for land with a particular use status, affects the prices of land with a use status that generates less income. Scarceness and scantiness of land resources with particular parameters, along with a demand growth for land with various spatial functions, result in increase in value of the land. The higher land value should be reflected in higher lease rates.

For a group of subjects (investors) land lease is a form of land management enabling carrying out of an investment (running business) for a certain period of time. The lessee should take into account the periodical nature of benefits while assessing profitability. On the other hand, commune (land owner) leasing the land does not bear costs connected with property maintenance, security, and gains temporary revenues for the period of land lease. The types of land which are most often leased are the lands whose destined purpose (land use) is different (they are the stock of land for public use in the future) or is not defined (lack of the study of land use and development).

\section{Revenues from renting residential and commercial area out}

One of the commune's own tasks is to meet the housing needs of its population. By virtue of law ${ }^{4}$, (the Act on Protection of Tenants, Commune's Housing Stock and Changes to the Civil Code of 21 as of June 2001), the commune has to meet the low-income inhabitants' needs, and provide substitute accommodation and council flats.

The Municipal Council passes the long-term policies concerning the housing stock

\footnotetext{
${ }^{3}$ The Civil Code, Verbas Ltd. publishing house, Lublin, 2000, pp. 156-158.

${ }^{4}$ Journal of law Dziennik Ustaw No. 71, item 733 with amendments.
} 
management and the rules of renting flats out. In the process of setting the rental rates for 1 sq. $m$ of the commune-owned flat, certain factors are taken into account. The factors may either increase or decrease the use value of the property. These are e.g.

- building localisation (central, suburban) or dwelling type (multifamily, one dwelling house),

- localization of a flat in the building (floor, exposure to the sun),

- building and dwelling fittings (technical devices and building utility systems, their condition),

- the overall technical condition of the building.

Rent rates within the commune's stock are fixed by the head of commune (mayor) and they are compliant with the rental policy line. Until 2004 a ceiling of $3 \%$ of the replacement value was placed on rents ${ }^{5}$. Change of law as of 2005 enabled communes to increase rents and charges maximum twice a year (except of the ones independent on the owner). Moreover, low-income tenants may apply for rental discounts while using communal housing.

Rents for the commune-owned commercial premises and residential premises are set differently. The commercial premises are rented out in accordance with the Civil Code regulations and corresponding resolutions adopted by the executive (head of commune, mayor or city mayor).

By virtue of law, communes have to organize competitive tenders for renting commercial areas and rent levels are established on the basis of the highest bids. In case tenders conclude undecided, the premises are listed in the register of vacant premises. Any interested party may send an application for renting a particular unit. Rent levels are then established under negotiations.

\section{Fees for permanent management as a source of revenues for communes}

Permanent management (sometimes called continued management) is a right an organisational unit without legal personality may obtain to manage public properties. The organisational units may belong to the state or local governments (the Property Management Act art. 43).

The organisational unit holding the right of permanent management is entitled to:

- use the property for pursuing the unit's tasks (mainly its statutory goals),

- incur costs of land development, as well as reconstructions, outward and upward extensions and maintenance of buildings (after obtaining permission from the supervisory authority),

- rent the entire or part of the property, lease it out or grant the usufruct for a period no longer than the duration of the permanent management right after obtaining permission from the supervisory authority).

The right of permanent management is not assignable, transferable or inheritable. The organisational unit cannot transfer the right to another organisational unit. The beneficiary is obliged to pay annual fees calculated as a percentage of the property price, which cannot be lower than the value estimated by a property valuer. While calculating the fees, both the price of land and buildings are taken into consideration. The percentage rate $(0,3 \%, 1 \%$ and $3 \%)$ depends on the type of land use stipulated in the agreement, e.g. $0,1 \%$ for properties submitted for defence purposes, $0,3 \%$ for land to be used for technical infrastructure devices.

The percentage rate of 1\% may be increased by the commune's resolution (before the

\footnotetext{
${ }^{5}$ The replacement value of premises is calculated by multiplying usable floor area and the conversion indicator which is based both on the replacement cost of 1 sq. $\mathrm{m}$ of usable floor space, and the province governor's analyses.
} 
right of permanent management is granted). The properties submitted for permanent management of land used for public roads, parks, lawns, botanic gardens and zoos are exempt from fees. If a permanently managed property is used for more than one purpose, the percentage rate is determined for the purpose described in the right-transferring agreement as main. The annual fee may be revalued, though not more often than once a year and under the provision that the value of the property has changed. The head of commune, if permitted by the council, may grant a discount if the property is to be used for public purpose (e.g. technical infrastructure or charity) or it is listed in the national register of historic monuments.

\section{Revenues from imposing usufruct or easement burdens upon properties}

Communes (according to Art. 13 of the Property Management Act) may burden properties with the right of usufruct or easement. The usufruct (as well as easement) is an in rem right. It may be chargeable or free of charge. The fees are either agreed by the parties in the contract, adjudged by the court (in case of the usufruct by necessity), defined by the local government administration authority (in case of usufruct granted through administrative and legal procedures). The usufruct is an inalienable right. It expires on the usufructuary's death or if the right remains unexercised through the period of 10 years.

The property may be burdened with the right of easement to the benefit of another's property (dominant estate). An easement is the right that grants the owner of the dominant estate to use another's property (servient estate) for a specific purpose. It is also the right to prevent another from performing an otherwise lawful activity on their property. The easement can be for a personal use or a commercial use - i.e. an easement to a company which intends to build or already possesses devices for distribution of water, dump, gas, electricity or other similar devices. This is called utility easement and it grants the holder the right to use the servient estate for a limited purpose. The easement is similar to usufruct in terms of payment it may be either chargeable or free of charge. The same rules of setting fees apply for both rights.

\section{Conclusion}

Properties which belong to communes are diverse. Irrespective of the function they serve, there is a need for efficient use of the subject properties in the process of rendering public services by communes.

One of the communal instruments promoting active management of the land stock is the choice of rights the commune will grant. Under Polish law, properties belonging to communes may be sold, burdened with the right of perpetual usufruct, permanent management, usufruct or easement. They may also be leased out or rented. Each of the listed form generates certain revenues to the commune's budget.

\section{Summary}

Commune-owned properties serve numerous functions in communes' tasks. The aim of managing municipal properties is the efficient use of the subject properties in the process of rendering public services by the commune. In accordance with the legal regulations within the civil-legal relations, local governments may make their properties available to various entities. They may sell the subject properties, lease and rent, grant the perpetual usufruct, common usufruct, permanent management or burden them with the easement right. The bundle of these rights is a source of communes' revenues. These issues are the subject of the study. 


\section{References}

Borodo, A. (2004), Samorzad terytorialny. System prawno finansowy, Wyd. Lewis Nexis, Warsaw.

Dylewski, M., Filipiak, B., Gorzałczyńska-Koczkodan, M. (2006), Finanse samorzqdowe. Narzędzia. Decyzje. Procesy, Wyd PAN, Warsaw.

Cymerman, J. (2009), System opłat od nieruchomości, Olsztyn.

Łaguna, T.M (2002), Aktywne gospodarowanie nieruchomościami szansq zwiększenia wplywów dla budżetów gmin, [w:] Finanse publiczne w skali lokalnej i regionalnej, edit. M. Adamowicz, wyd SGGW, Warsaw.

Miszczak, M. (2009), System podatków i opłat samorzqdowych w Polsce, C.H. Beck publishinghouse, Warsaw.

Patrzałek, L. (2004), Finanse samorzadu terytorialnego, Wroclaw University of Economics publishing house, Wrocław.

Ruśkowski, E., Sałachna, J.M. (2007), Finanse lokalne po akcesji, wyd. 2, Oficyna Wolter Kluwer business, Warsaw.

The Civil Code (2000), Verbas Ltd., Lublin.

The Property Management Act of 21.08.1997 (journal of laws Dziennik Ustaw of 2004, No. 261, item. 2603, with amendments). 